\title{
Obituary
}

\section{John Anthony ‘Tony’ Allan 29 January 1937-15 April 2021}

\author{
Salem El-Maiar \\ London Water Research Group
}

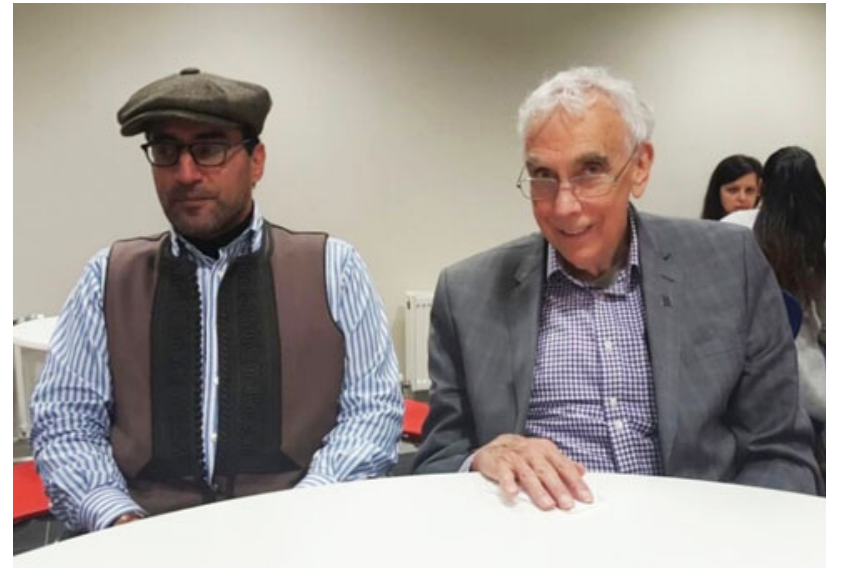

Figure 1. Photograph of Salem El-Maiar and Tony Allan in the senior common room, SOAS, October 2017. Source: Dr Saad Alghariani.

Tony Allan, Emeritus Professor of Geography at the School of Oriental and African Studies (SOAS) and King's College London for nearly fifty years, died on 15 April 2021 of throat cancer. He was 84. John Anthony Allan was born in Newcastle upon Tyne on 29 January 1937. Following his initial schooling in Newcastle, Tony embarked on a bachelor programme at Durham University gaining a first-class BA in Geography. His university friends remember him for his outstanding intellect and for being on a different and higher level than the rest of the students. To the surprise of many, he did not take up an academic career immediately after his degree.

After Durham, it took him six months to sign up for army national services and he was among the last groups to spend two years serving, from February 1959 to February 1961. The first year was spent augmenting his surveying expertise - gained at university - in army training schools in Chatham and Newbury; the second was spent in the Aden Protectorate and Oman as a junior officer running a survey team collecting map information. Tony then did various jobs in northeast England for the next five years, during which time his mother passed away.

In 1966, while Tony was preparing to join British Aluminum in London for a new job, he received a phone call from his old friend at Durham, Keith McLachlan, who persuaded him to apply for a fellowship position at SOAS working on Libya. This led to what Tony himself described as an uncharacteristically sudden decision to switch careers. It began what would turn into a nearly fifty-five-year career in science. From the outset, he was involved in organizing the Libyan University-London (SOAS)

Cite this article: El-Maiar S (2021). John Anthony 'Tony' Allan 29 January 1937-15 April 2021. Libyan Studies 52, 7-8. https://doi.org/10.1017/lis.2021.17
University Joint Research Project and contributing a chapter entitled 'Land use and cropping patterns in Libya'. It was an interdisciplinary research that lasted three years and gave him the basic knowledge of understanding the allocation and management of the water resources in Libya and subsequently in the MENA region. This project involved visiting Libya various times and led him to complete his PhD thesis in 1971 entitled 'Changes in the economic use of land and water in the vicinity of Tripoli'.

During his time in Libya, Tony made many friends, with academics, staff and students at the University of Libya and he also joined Professor Richard Goodchild to become a founding member of the Society for Libyan Studies fostering academic links between British and Libyan scholars. He played a pivotal role in diversifying the activities of the society. Immediately after acquiring his $\mathrm{PhD}$, Tony started lecturing at SOAS, and with his lifetime friend Keith McLachlan and Edith Penrose he wrote Libya: Agriculture and Economic Development in 1973. In 1981 he wrote Libya: The Experience of Oil, and a year later Libya Since Independence, Economic and Political Development.

Tony chaired the British Society for Middle Eastern Studies conference in 1986. He was also a pioneer in the then emerging field of remote sensing, which implied the collection of geographical data via imagery captured by satellite and he was a former Chairman of the Remote Sensing Society. Tony was appointed a professor at SOAS in 1992 and devoted his time to two topics: Earth Observation, which is the use of satellite data and images to detect environmental conditions; and water. He ceased working on the former when the SOAS geography department moved to King's College and he followed it there in 2001. He retired a year later.

The period after his retirement was been the most rewarding time of his scientific life. Tony identified the concept of 'virtual water' in 1988. Virtual water is the water embedded in our food. Over the next twenty years the importance of the idea gained currency and international recognition. On 19 March 2008 Professor Allan was named by the Stockholm International Water Institute as the 2008 Water Prize Laureate. He was also the recipient in 2013 of the Florence Monito Water Prize and the Monaco Water Prize. His work on virtual water reshaped thinking on water management and policy, and had a global impact. Water scientists and water and food policy makers routinely take the virtual water 'traded' in food into account. During this period he authored and edited twelve books on natural resource topics and published many articles in learned journals.

An 'outside the box' thinker, Tony further developed the idea and terminology of 'hydro-hegemony' in which the analysis of power is the key factor in understanding and informing water policy. He was consequently the founder of the London Water Research Group (LWRG), an independent forum for discussing the sensitive issues concerning hydro-politics, science, social and governance aspects of water resource use and sharing. 
His ideas now underpin metrics such as the water footprints used by multinational corporations to account for their impact and dependencies on water resources. In the UK, learning about virtual water is part of the A-level geography syllabus.

Tony was a pioneer scientist who was dedicated to creating a fair solution for water usage in water-scarce regions. He was known across the globe by many scholars, think tanks, researchers, politicians, international corporations and scientific institutions. He will be greatly missed by the academic community.

His love for Libya was deep-rooted and he was always extremely concerned with the development of natural and human resources in the country.

I arranged for Tony, Brian Chatterton, a former Australian minister of agriculture and Lynne Chatterton, a former rural policy advisor to the South Australian Premier, to visit Libya in 2009 where they gave lectures at the universities of Tripoli, Benghazi and Omar Al-Mukhtar in what was meant to be his farewell visit to his beloved Libya.

Until the last weeks before his death, Tony was still teaching, supervising and publishing.

His passing away is a great loss to Libya's academic tradition and to Libyan links not only for the Society for Libyan Studies, but also British and Libyan universities at large.

Beyond his scientific work, Tony was also a passionate educator, communicator and mentor: 'a good idea, if not well communicated, is not a good idea' he always reminded his students.

Tony gained and kept everyone's deep respect. It is hard to imagine the future without being able to contact him to access his unique expertise and the amiable conversation that would take place. He was extremely humble, kind but also challenging and most importantly he was a tremendous source of inspiration and motivation. His great legacy will continue.

$\mathrm{He}$ is survived by his long-term partner Mary O'Shea. 